\title{
Communication Therapy Model for People with Asperger Syndrome
}

\author{
F P Kusuma, Subyantoro, A Su'udi and H B Mardikantoro \\ Graduate School, Universitas Negeri Semarang, Indonesia \\ Coresponding email: fandyprasetyakusuma@gmail.com
}

\begin{abstract}
Cultural transformation in the industry 4.0 era has become an inevitable phenomenon. One of its impacts can be found in the form of human interaction revolution. Individuals who are unable to manage this wind of change shall be left behind in the current competition. People with Asperger Syndrome (PAS) is known as a group that belongs to autism spectrum disorder. They are characterized by outstanding skills in specific area but have impairment in communication skill. Thus, PAS have the possibility to be outcasted in the post-modern constellation. This study focuses to bridge the gap between PAS and society by formulating a prototype of communication model based on assitive technology. Hymes' (1974) theory of communication components and Saville-Troike's (2003) inter-relation components were synthesized and implemented on mobile computing interaction platform for PAS. This formulation produces a contextual conversation therapy device named Communication Tunnel Model which could be progressively customized for PAS with various backgrounds.
\end{abstract}

Key words: communication therapy, Asperger syndrome

\section{Introduction}

Inclusion has become an important sophisticated notion reffering to the 21 st century communication characteristics. Global village phenomena, according to Hafez (2007), provide opportunities for everyone to be actively involded in the limitless relationship constellation. The rising existence of netizenship marks the collapsing of heterogeneity wall. This tremendous revolution lays a fresh social connection pattern. Borderless acceptance is a term to label a novelty in postmodern dealing. The merging of some groups of people which were considered and labelled as the outcasted clusters like disabled inividuals in broad communication is a strong evidence of the transformation.

In fact, there are still some untouchable areas that need to be explored. The fulfillment of equality vision in mondial relationship should not ignore the existence of these eliminated communities. This study focuses on a specific clique called People with Asperger Syndrome (PAS). The syndrome is registered in the Fourth Edition of Diagnostic and Statistical Manual of Mental Disorders (DSM-IV) as one variant in the autism spectrum based on American Psychiatric Association (2000). PAS are characterized by the display of superior knowledge in specific subject shown by the excessive pedandic talks on a solitary topic. The deficiency in social interaction ability is aggravated by their extreme repetitive behavior and mere talk only to restrictive interests (Sue,
Derald, and Stanley, 1994). Mutual inteligibility among the conversational elements was difficult to achive due to conditions of PAS. The awkwardness use of language in the conversational context (Attwood, 2008) and their inability to comprehend the unwritten norms in the natural discourse as stated by Barnhill (2004) as the informal one have become communication barriers between PAS and the common society (Friedrich and Shaughnessy, 2015).

The generic PAS' psychological impairments as briefly shown above strictly treasure the potential of ruining social interaction. Thus, allowing a sort of systematic intervension (Wilkinson, 1998) in defined interactional domains of PAS' daily life such as everyday situational contexts is pivotal. Casuistical interest on PAS is managed by construction of the communicational model of therapeutic approach. It is personally arranged to maintain the existence of this community within the area defined by Scott (1990) as the public transcript.

\section{Methods}

Four adult PAS were intentionally chosen in this study. Each of them performed their distinct personal interest in the various favourite fields, they shared similar description at the social acceptance domain. As mapped by Todorov and Mariana (2012), their impairment had emerged barriers rather than sustaining normal conversation. Besides, there were some factors 
such as the individuality turn-taking (O'Toole, 2012), psychologically irritating speech (Hall, 2005), and odd vocabulary creation (Jackson, 2004) which strengthen the evidence of their Asperger condition.

The subjects were codified by combining the terms of PAS and the numerical form. The codification of the PAS is presented as follows: S1 (the first subject), S2 (the second subject), S3 (the third subject), and S4 (the fourth subject). They lived in separated place and held different societal backgrounds. Due to the aspect of confidentiality, their real name was encoded. The compendious description of the four is listed as follows.

a. PAS-S1

The first subject (PAS-S1) was male and married man. By 2018, he was 33 years-old. He had a remarkable interest in cinematic field. The topic of his everyday conversation was exceedingly dominated by mere film world terminologies. He faced difficulty in finding permanent work because of his inability in social interactions.

b. $P A S-S 2$

Cleanliness of the house was the only concern shown by this second subject (PAS-S2). He was male who was greatly obsessed in talking on single topic, i.e hygiene. This over elaborated talks brought serious problem in sustaining the interaction with his inner society. He was 27 years-old.

c. $P A S-S 3$

The third subject (PAS-S3) was male and 23 years-old. Information technology usage was his only interest. It was clearly visible from his daily activities and the conversational topic.

d. PAS-S4

Among the others, PAS-S4 was the oldest one. And the only female. She was 55 years-old. She was very interested in singing activity. She frequently forced her talking partners to sing along and listen to her explanation of the song information.

\section{Results and Discussion}

In the beginning phase, ethnography of communication approach was used to find the particular language behaviors (Matei, 2009). Then, semi-longitudinal observation which took 24 months was held to gather holistic communication behaviors and patterns showed by the subjects. Afterwards, the activation of Hymes' (1974) Mnemonic of SPEAKING was implemented on the thick description of PAS-S1 to PAS-S4 which were then collected and carefully composed.

The construction of communication patterns from PAS-S1 to PAS-S4 was carried out by analyzing the components of their daily talks. The analysis dealt with different components such as setting, scene, participant, end/ purpose of talks, act sequences, key/ tone, instrument, norms of interaction, norms of interpretation and genre. They resulted in two major components influencing the sustainable conversations between PAS and their interlocutors. Those two components were key/ tone and instrument factors. It was found in this study that the subjects were able to follow the adjacency pairs rules when those two factor were activated. The ethnographic analysis shows that level of understanding was fulflled by the subjects when the mind of the speech partner is transmitted through these two component paths. The visible general reaction was that they performed good responses to acoustic codes and visual codes.

The following figure depicts dominant influence of those two components in the context of strategic communication to PAS. The segmented pyramid form does not represent the hierarchical structure. Rather, the triangular format with the pitch cone is designated as a representation of the protrusion of two components with significant influence. Intercomponent segmentation is not intended to be a discrete separator, but rather a representation of interrelations that are dependent on each other and their effects tend to be fluid.

Based on that pattern the authors propose a model in the form of prototype communication channel recommended as an alternative to communicate with PAS. This model is related to aspects of language functionality (Tagliamonte, 2007) which in this context aims to convey speaker intention to PAS.

In this study, the key and instrument components are considered quite effective to make PAS capable of decoding the intention of the speakers. Correlated with the SavilleTroike's (2003) inter-relation component, there will be filtering process of components from S.P.E.A.K.I.N.G. The prototype in this study is called as Communication Tunnel Model (CTM) which focuses on the usage of tonal and instruments aspects. The model is broadly 
opened to some developmental method such as SQ3R (Widianto and Subyantoro, 2015) in order to invite PAS in communication activities. The simple prototype of CTM is illustrated below.

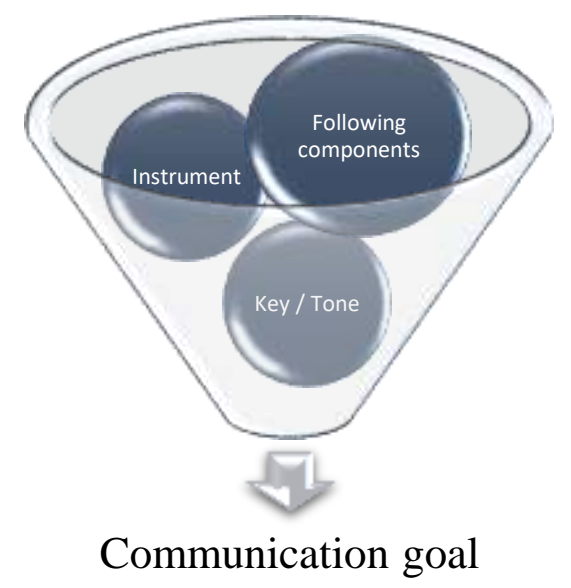

Figure 1. The CTM

Referring to the orientation of the use of CTM, the role of genre component, setting, participant, end, act sequences, norms of interaction and norms of interpretation cannot necessarily be ruled out. The existence of the influence of each fixed component must be calculated even though the intensity is not as strong as the key and instrument components. The use of the model is casuistic. It remains open to the probability of being implemented to subjects with a socio-cultural heterogeneous background (Foley, 2002) as an alternative solution in fostering polite and felicitous communicative relationships with PAS.

Implicitly, CTM is a structured logical sequence that able to be developed through computer programming language as a pioneer of special software for PAS which in general supports the effectiveness of communication with people with disabilities (Schneider, 2001). In general, this software orientation is a simulator for People with Asperger Syndrome to practice in various communication events with features of communication components that can be customized.

In an interdisciplinary matrix, the results of this preliminary study are a glimmer of the fact that the inclusive civilization of society began to emerge in Indonesia (Taylor, 2007). The findings can be developed into a public policy development proposal that accommodates PAS interactional rights in the context of social life in order to address global village phenomenon in the context of Indonesian diversity. Thus, the nature of PAS as homo loquens are well preserved (Chernigovskava, 2004).

In the realm of disruptive era, the CTM convergence with computing algorithmic platform has reached its urgency. Combining the design of thinking and the approach in system engineering (Durantin, 2007) is possibly manifested by implementing the model into a user friendly mobile application. This solution is going to help PAS build relationship along with post-modern society.

\section{Conclusion}

PAS as one of the inseparable global communities has met its new hope. Their impairment in constructing the sustainable relationship with normal people possibly occurs through the use of Communication Tunnel Model. The continuous development of this prototype is progressively implemented on various mobile computing platform. The main goal is right equality of communication among PAS and others.

\section{References}

Association, American Psychiatric. (2000). DSM-IV-TR Diagnostic and Statistical Manual of Mental Disorders, Fourth Edition, Text Revision. Washington D.C.: American Psychiatric Association.

Attwood, Tony. (2008). The Complete Guide to Asperger's Syndrome. Philadelphia: Jessica Kingsley Publishers) 
Barnhill, Gena P. (2004). Asperger Syndrome: A Guide for Parents and Educators (North Kansas City: NASP)

Chernigovskaya, Tatiana V. (2004). Homo Loquens: Evolution of Cerebral Function and Language Journal of Evolutionary and Physiology, 40(05). 495-503.

D., Stephan F. (eds) Complex Systems Design \& Management. CSDM 2016. Springer, Cham.

Durantin A., Fanmuy G., Miet S., Pegon V. (2017). Disruptive Innovation in Complex Systems. In: Fanmuy G., Goubault E., Krob.

Foley, William A. (2002). Anthropological Linguistics: An Introduction. Massachusetts: Blackwell Publishers Inc.

Friedrichs, Terence Paul \& Shaughnessy, Michael F. (2015) A reflective conversation with Terry Friedrichs on teaching academics to gifted students with Asperger Syndrome Gifted Education International. 31. 41-53.

Hafez, Kai .(2007). The Myth of Media Globalization . Malden: Polity

Hall, Kenneth. (2005). Asperger Syndrome, the Universe and Everything London: Jessica Kingsley Publishers.

Hymes, Dell. (1974). Foundations in Sociolinguistics: An Ethnographic Approach Philadephia: University of Pennsylvania Press

Jackson, Luke 2004 Freaks, Geeks and Asperger Syndrome: A User Guide to Adolescence. (London: Jessica Kingsley Publishers)

Matei, Madalina. (2009). The Ethnography of Communication Bulletin of the Transilvania University of Braşov. 2(51) Series IV: Philology and Cultural Studies.

O'Toole, Jennifer Cook. (2012). The Asperkid's (Secret) Book of Social Rules: The
Handbook of Not-So-Obvious Social Guidelines for Tweens and Teens with Asperger Syndrome-Kindle Edition (London: Jessica Kingsley Publishers).

Saville-Troike, Muriel. (2003). The Ethnography of Communication: An Introduction - Third Edition (Oxford: Basil Blackwell).

Schneider, James, Philip S. Antón dan Richard Silberglitt. (2001). The Global Technology Revolution - Bio/Nano Materials Trends and Their Synergies with Information Technology by 2015 (Santa Monica: RAND).

Scott, James C. (1990) Domination and the Art of Resistance: Hidden Transcripts (New Haven: Yale University Press).

Sue, David. Derald Sue \& Stanley Sue. (1994). Understanding Abnormal Behavior (Boston: Houghton Mifflin Company)

Tagliamonte, Sali A. (2007). Analyzing Sociolinguistic Variation: Key Topics in Sociolinguistics (Cambridge: Cambridge University Press).

Taylor, P. (2007). Urban Policies for the Social and Spatial Integration of International Migrants. UNESCO and IUAV EGM Cosmopolitan Urbanism 13 (1).

Todorov, Stefan dan Mariana Arnaoudova. (2012). On Differential Diagnosis between Autistic Disorder and Asperger's Syndrome Journal of IMAB 18. Book 3.

Widianto, Eko \& Subyantoro. (2015). Peningkatan Keterampilan Membaca Teks Klasifikasi Menggunakan Metode SQ3R dengan Media Gambar Jurnal Pendidikan Bahasa Sastra Indonesia JPBSI 4 (1).

Wilkinson, Krista M. (1998). Profiles of Language and Communication Skills in Autism Mental Retardation and Developmental Disabilities Research Reviews 4 Issue 73-79. 